\title{
The Grammar of Knowledge: A Look at Feminism and Feminist Epistemologies
}

Valerija Vendramin, Educational Research Institute, Ljubljana, Slovenia

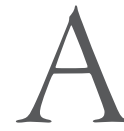

$s$ a postscript and by way of a response to all the contributors in this issue of The School Field, I would like to "wrap up" all of the subjects presented into a single general theme: feminist epistemologies. Better still: this may be seen as some sort of conversation I wish I once had, but have not (perhaps an opportunity for a roundtable on this topic will arise some day). At the same time, I wish to thank the authors all for their cooperation and, after all, for opening up new intellectual spaces and reflecting on those already in place. The theme of teaching feminism is important, even more so in the present times, as is obvious from all of the issues raised and dealt with by the authors in this issue. But let me first start with feminism. Feminism is many things to many people, says Helen Longino, "but it is at its core in part about the expansion of human potentiality" (Longino, 1987, p. 60; see also Vendramin, 2018, p. 75).

At this point, let me briefly deal with the singular/plural issue raised by the title of this text, i.e.: feminist epistemology vs. epistemologies (FE). FE is an approach to epistemology (rather than a single school or theory) that uses gender as a central category. Gender is indeed a central category, but - as a sort of contribution to more precise thinking - other axes of discrimination and marginalisation are included. According to Marianne Janack (n.d.): feminist epistemology “identifies how dominant conceptions and practices of knowledge attribution, acquisition, and justification disadvantage women and other subordinated groups, and strives to reform them to serve the interests of these groups". Phyllis Rooney says that "feminist epistemology (as encompassing a range of epistemological projects informed and linked by efforts to uncover the political and 
epistemological fallout of the epistemic disenfranchisement of women and other 'others') proceeds in fruitful conversation with a range of approaches or directions in epistemology, and it is unique in this kind of epistemological flexibility" (Rooney, 2010, p. 21).

This explains why feminist epistemology can sometimes also be spoken about in the plural (Janack, n.d.). ${ }^{\mathrm{I}}$ Feminist epistemologies contain an important feature that sets them apart from other traditions (to which they are indebted in various ways and extents) - the emphasis on the epistemic salience of gender and the use of gender as an analytical category in discussions, criticisms and reconstructions of epistemic practices, norms and ideals (ibid.).

Phyllis Rooney (20II, pp. 5-6) in this regard deals with another important issue, namely with the "persistent refrain in mainstream epistemology circles that feminist epistemology is not epistemology 'proper,' and thus not something with which epistemologists need concern themselves". This attitude "has ranged from hostile to dismissive to limited acknowledgement" (ibid). These dismissals, ${ }^{2}$ writes Rooney, "are problematic for epistemological as well as political reasons /... and/ are quite revealing of unexamined assumptions about epistemology 'proper"' (ibid., p. 6). Hence, not only is a gendered subject marginalised in a research study or inquiry, but the very discipline dealing with being a gendered knowing subject (and all the categories that go along with it, such as objectivity, justification, reason etc.) and researching the consequences of this is also marginalised.

This epistemological theme appears in many articles here, sometimes explicitly, sometimes less so. But it is there in different ways. As Nina Lykke puts it: rather than homogenising, it is important to provide a heterogeneous feminist space for comparing notes (Lykke, 20IO, p. 135). ${ }^{3}$ And, as she continues:

My claim is that this particular thinking technology may make more visible current feminist commitments to rethinkings of bodily and transcorporeal materialities, and to the unfolding of innovative kinds of knowledge producing practices which transgress both positivism, social

Feminist philosophers "have articulated three main approaches to this question - feminist standpoint theory, feminist postmodernism, and feminist empiricism" (Janack, n.d.). These three approaches are given here for information only, they often converge and no doubt have developed over time.

2 There is talk about political correctness and agendas - about something that allegedly has no place in science. For a little more on the "criticism" of feminist epistemology, see e.g. Vendramin, 2009. 
constructionism, and post-modern relativism and anti-foundationalism. A strong commitment to ethics - and a belief in an inextricable link between epistemology, ontology, and ethics - is also a common denominator of the diversity of heterogeneous theories /.../ (ibid.).

Accordingly, these strands of thought lead us to dealing with the taken-for-granted, which can be expanded in various directions, one of them being meanings acquired in everyday life. ${ }^{4}$

But, in connection to delineation of what feminist epistemology (or epistemologies) is, Elizabeth Anderson, for example, warns as following:

Feminist epistemology has often been understood as the study of feminine "ways of knowing." But feminist epistemology is better understood as the branch of naturalized, social epistemology that studies the various influences of norms and conceptions of gender and gendered interests and experiences on the production of knowledge (Anderson, 1995, p. 50).

This quite general presentation (general in the sense that I chose it, not because Elizabeth Anderson's thinking is too general in defining it) can be complemented, for instance, with Iris Van der Tuin's definition (2016):

Feminist epistemology refers to the feminist engagement with questions of truth, objectivity, method, and the knowing subject. /.../ The key question of feminist epistemology as a field of inquiry involves the epistemic status of the knowledge produced by privileged and marginalized subjects. Where to draw the line between knowledge and prejudice? In sum, feminist epistemology pertains to the intersection of knowledge and power.

This last sentence is particularly important here, as knowledge is always someone's knowledge (and by "someone" in this case I mean a particular social group). Wherever there is significant social stratification, there are likely to be epistemic effects (Grasswick, 200I, p. xv) - i.e. an influence on the concepts of knowledge, inquiry, justification and the like.

A famous phrase by Donna Haraway goes like this: "Vision is always a question of the power to see" (Haraway, 1991, p. 192), and so the assertion made by the researcher that she or he watches from everywhere and sees everything, that she or he has no desires, needs, convictions or backgrounds, is contentious (Haraway, 1991, p. 192) and an evasion of

To briefly return to the sphere of education, this especially concerns both the curriculum and the hidden curriculum. Particular attention should be paid here to the hidden curriculum because a certain level of doubt and reconsideration is required in order to detect and analyse it (see e.g. Bahovec \& Bregar-Golobič, 2004). 
responsible discourse (my italics). This is a view from a position that is transcendent, which means that I/we/someone is speaking (better: claims to be speaking) above the level of human activity, above politics and power - and beyond lived experience.

In contrast with more traditional definitions of objectivity, feminist objectivity is achieved not through transcendence - this would be the "god-trick" (done by the allegedly disembodied scientist, which is a traditional positivist view of science) of being the Deity in relation to the rest of the universe (Haraway, 1991, p. I83 ff). ${ }^{5}$ It is done through a dynamic engagement with partial perspectives stemming from marginalised positions. We should not forget the ethical and moral implications here, i.e. the challenge and responsibility to recognise power relations. Iris Van der Tuin describes it in this way: "one of the most important methodological innovations of feminism has been the distinction between 'studying up' and 'studying down'. Studying down implies that asymmetrical power relations are reconfirmed easily in research. The alternative, studying up, is the standpoint theoretical model of researching from the lives of marginalized subjects" (Van der Tuin, 2016).

As already mentioned, feminist epistemology is not research into some kind of easily and generally detectable gender-specific, i.e. feminine, ways of knowing, styles of thinking, intuitions, methodologies and ontologies that govern or characterise cognitive activities (Anderson, 1995, p. 62; Vendramin, 2018) - at least this is my understanding. As Phyllis Rooney states:

The idea of "women's/feminine ways of knowing" has indeed surfaced in feminist epistemology, but the primary focus has been on how problematic the idea is. Among other things, it involves generalizations about women (across different races, classes, and cultures, for example) that have been the focus of significant critical scrutiny in the past three decades of feminist theorizing (Rooney, 2010, pp. 6-7).

Such understanding avoids dubious claims about feminine cognitive differences and enables feminist research in various disciplines to pose deep internal criticism of mainstream research (Anderson, 1995, p.

Haraway's text entitled "Situated Knowledges: The Science Question in Feminism and the Privilege of Partial Perspective" from Haraway, 1991, is one of the most important texts on epistemological issues (I do not wish to say "in feminism" here, because it should be discussed wider). See above about feminist epistemology and "epistemology proper". Haraway points out that feminists are interested in science projects "that offer a more adequate, richer, better account of a world, in order to live in it well and in critical, reflexive relation to our own as well as others' practices of domination and unequal parts of privilege and oppression" (Haraway, 1991, p. 187). 
50). ${ }^{6}$ In any case, this question is quite hotly disputed, explains Londa Schiebinger, and remains in the realm of theory (Schiebinger 1999, p. II; see also Vendramin, 2018). In my opinion, the statement of all the women knowing the world differently (and, e.g., doing science differently) ${ }^{7}$ as all the men is too basic, too one-dimensional, not least because gender should be understood not primarily as an attribute of individuals but as an axis of social relations (Anderson, 1995; Grasswick, 2008). This means that, scepticism "about the idea of any unitary women's consciousness or unitary women's experience" (Bart, 1998) should be present. Being a feminist is a political identity, and political identities are "created in the flux of ideology and practice. They are not natural extensions of particular kinds of psyches or bodies" (Felski, 2000, p. 198).

Feminist theory began as an analysis of the ways in which knowledges discriminated against women and helped to develop and perpetuate harms done to women, both conceptually and materially; it emerged through a recognition of the inadequacy of existing models to explain women's positions in the past and their potential for change in the present and future. (Grosz, 2010, p. 49).

But, according to Elizabeth Grosz, it is important for the research focus to be both conceptual and empirical (although she states that her own focus is conceptual rather than empirical, so I hope I am not stretching the interpretation of her words too far),

not because the empirical has no place, but because, without a conceptual frame, the empirical has no value, no context, no power, it simply is. The empirical is given without some understanding of how it comes to be, without some assessment of its historicity and its potential to be otherwise. Only a framework, a context, which explains the forces that produce its givenness, can also show how it may be undone, or made differently (ibid.).

This is very much in line with what Donna Haraway writes in her seminal work Simians, Cyborgs and Women (1991, p. 82): feminism is “a

6 Some additional questions: is there such a thing as feminist science, is there perhaps a "female style" in science, do women do science differently to men (if so, how would this research differ from traditional research) (Vendramin, 2018, p. 76)?

7 This is a very vast theoretical territory into which we unfortunately cannot venture at this point. The thesis of automatic epistemic privilege (in other words: superior insight), which means that those who are oppressed or marginalised always know more, or always know better, because of their social/political location cannot always be backed up (see Wylie \& Sismondo, 20I5; italics are mine). For a reflection on this, see Felski, 2000, which in my opinion is a very succinct contribution on the politics of feminist identity. 
search for new stories, and so for a language which names a new vision of possibilities and limits. That is, feminism, like science is /.../ a contest for public knowledge".

Similarly, Eva Bahovec explicitly places feminism in the framework of epistemology and notes: the epistemological struggle of feminism is a clash with the category of the self-evident, with everything perceived as given, natural and unchangeable: "with everything that is only an appearance and therefore misleading" (Bahovec 2007, pp. 35-36). In short, I opt for the permanent resistance of the feminist epistemic subject towards the taken-for-granted, including itself and its constructions (Vendramin, 2014, p. 199).

We should return here to women's epistemic disenfranchisement. Phyllis Rooney believes this disenfranchisement needs to be made visible as women have been dismissed as "serious reasoners and knowers in a variety of knowledge areas and disciplines as well as in philosophy /and it/ continues to be a defining project in feminist epistemology" (Rooney, 20I0. p. IO). Thus, to remain within this line of thinking with the help of Miranda Fricker: "The cause of testimonial injustice ${ }^{8}$ is a prejudice through which the speaker is misjudged and perceived as epistemically lesser (a direct discrimination). This will tend to have negative effects on how they are perceived and treated non-epistemically too" (Fricker, 2017a, p. 54). But let us now turn the perspective around: those that are non-epistemically perceived to hold less "value" cannot authorise themselves epistemically in society as a whole (such as currently exists). So, to "the epistemological question 'Who can be legitimate knowers?' the answer has historically been, 'not women'” (Bart, 1998).

In short let me conclude, that feminist inquiries have "made significant contributions to the epistemological terrain as regards questions such as who can be 'knowers', or what sorts of experience can count as justification of knowledge claims" (Bart, 1998).

So, let us return to Nina Perger, Metka Mencin and Veronika Tašner's article to reflect on FE and threats posed to academia by governing neoliberal ideology that is "making deals with (extreme) right-wing political movements". Or, for example, reflect on endeavours "to create epistemological alliances with critical studies such as decolonial or antiracist research studies, among others", as writes Biljana Kašić. Or, as we can read in Renata Šribar's article, it is important to "transpose feminist epistemologies to class" if we want to practise feminist pedagogy. Similarly, Ana

8 Injustice as a "wrong done to someone specifically in their capacity as a knower" (Fricker, 2007 b, p. I) or a subject of knowledge (ibid., p. 5). 
Mladenović, among other things, gives an example of how to realize this approach in a feminist classroom. Further, we can venture into mediascape with Mirjana Adamović or look into the discourses of the "crisis of masculinity" and "feminisation" in school context with Majda Hrženjak, not to mention "discussions about gender and language, the diversity and rights of socially disadvantaged groups" that Mojca Šorli speaks of.

Here is our "power to see" (Haraway, 1991, p. 192).

\section{Literature}

Anderson, E. (2020). Feminist Epistemology and Philosophy of Science. In E. N. Zalta (Ed.), The Stanford Encyclopedia of Philosophy. Retrieved September 25, 2020, from plato.stanford.edu/archives/spr2020/ entries/feminism-epistemology/.

Anderson, E. (1995). Feminist Epistemology: An Interpretation and a Defense. Hypatia, Io(3), 50-84.

Bahovec, E. D. (2007). Freud, ženska in popotnikova senca. Delta.

Bahovec, E. D., \& Bregar-Golobič, K. (Eds.) (2004). Šola in vrtec skozi ogledalo. DZS.

Bart, J. (1998). Feminist Theories of Knowledge. The Good, the Bad, and the Ugly. Retrieved December II, 2020, from Feminist Theories of Knowledge: The Good, The Bad, and The Ugly (sbc.edu).

Felski, R. (2000). Doing Time. Feminist Theory and Postmodern Culture. New York University.

Fricker, M. (2017a). Evolving Concepts of Epistemic Injustice. In I. J. Kidd, J. Medina \& G. Pohlhaus, Jr. (Eds.), The Routledge Handbook of Epistemic Injustice (pp. 53-60). Routledge.

Fricker, M. (2017b). Epistemic Injustice. Power \& the Ethics of Knowing. Oxford University Press.

Grasswick, H. E. (20II). Introduction: Feminist Epistemology and Philosophy of Science in the Twenty-First Century. In H. E. Grasswick (Ed.), Feminist Epistemology and Philosophy of Science. Power in Knowledge (pp. xiii-xxx). Springer.

Grosz, E. (2010). The Untimeliness of Feminist Theory. NORA - Nordic Journal of Feminist and Gender Research, I8(I), 48-5I.

Janack, M. (n.d.). Feminist Epistemology. The Internet Encyclopedia of Philosophy. Retrieved September 25, 2020, from http://www.iep.utm. edu/fem-epis/.

Longino, H. (1987). Can There be a Feminist Science? Hypatia, 2(3), 51-64. 
Lykke, N. (2010). The Timeliness of Post-Constructionism. NORANordic Journal of Feminist and Gender Research, I8(2), I3I-I36.

Rooney, Ph. (2011). The Marginalization of Feminist Epistemology and What That Reveals About Epistemology "Proper”. In H. E. Grasswick (Ed.), Feminist Epistemology and Philosophy of Science. Power in Knowledge (pp. 3-24). Springer.

Schiebinger, L. (1999). Has Feminism Changed Science? Harvard University Press.

Van der Tuin, I. (2016). Feminist Epistemology. Wiley Online Library. Retrieved September 24, 2020, from https://onlinelibrary.wiley.com/ doi/abs/10.1002/9781118663219.wbegsso42.

Vendramin, V. (2018). Women and Science: Feminist Shifts in Theory and Practice. In M. Gadpaille, V. Kondrič Horvat \& V. Kennedy (Eds.), Engendering Difference: Sexism, Power and Politics (pp. 72-84). Cambridge Scholars Publishing.

Vendramin, V. (2015). Epistemological (and Some Methodological) Aspects of the Gendered Perspective in Science. In M. Ule, R. Šribar \& A. Umek-Venturini (Eds.), Gendering Science: Slovenian Surveys and Studies in the EU Paradigms (pp. 6I-74). Echoraum.

Vendramin, V. (2014). Epistemic Subjects and Situated Knowledges: Women, Feminists and Others. In M.Z. G. de Abreu \& S. Fleetwood (Eds.), Women Past and Present: Biographic and Multidisciplinary Studies (pp. 194-200). Cambridge Scholars Publishing.

Vendramin, V. (2009). Od kod prihajajo dejstva?: feminizem in transformacije nekaterih temeljnih epistemoloških pojmov. Dialogi, 45(II/I2), $57-68$.

Wylie, A., \& Sismondo, S. (20I5). Standpoint Theory. In J. D. Wright \& M. E. Lynch (Eds.), Science In: International Encyclopedia of the Social and Behavioral Sciences (pp. 324-330). Elsevier. 